\title{
Regional Connection under the Belt and Road Initiative
}

The Prospects for Economic and Financial Cooperation

\section{Edited by Fanny M. Cheung and Ying-yi Hong}

First published 2019

ISBN: 978-1-138-60749-1 (hbk)

ISBN: 978-0-429-46717-2 (ebk)

5 China's Belt and Road

Initiative through the lens of Central Asia

Roman Vakulchuk and Indra Overland

(CC BY-NC-ND 4.0)

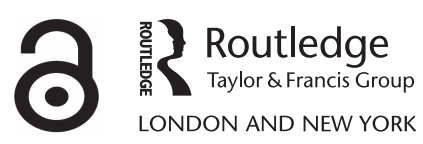


First published 2019

by Routledge

2 Park Square, Milton Park, Abingdon, Oxon OX14 4RN

and by Routledge

711 Third Avenue, New York, NY 10017

Routledge is an imprint of the Taylor \& Francis Group, an informa business

(c) 2019 selection and editorial matter, Fanny M. Cheung and Ying-yi

Hong; individual chapters, the contributors

The right of Fanny M. Cheung and Ying-yi Hong to be identified as the authors of the editorial material, and of the authors for their individual chapters, has been asserted in accordance with sections 77 and 78 of the Copyright, Designs and Patents Act 1988.

With the exception of Chapter 5 , no part of this book may be reprinted or reproduced or utilised in any form or by any electronic, mechanical, or other means, now known or hereafter invented, including photocopying and recording, or in any information storage or retrieval system, without permission in writing from the publishers.

Chapter 5 of this book is available for free in PDF format as Open Access from the individual product page at www.routledge.com. It has been made available under a Creative Commons Attribution-Non Commercial-No Derivatives 4.0 license.

Trademark notice: Product or corporate names may be trademarks or registered trademarks, and are used only for identification and explanation without intent to infringe.

British Library Cataloguing-in-Publication Data

A catalogue record for this book is available from the British Library

Library of Congress Cataloging-in-Publication Data

A catalog record for this book has been requested

ISBN: 978-1-138-60749-1 (hbk)

ISBN: 978-0-429-46717-2 (ebk)

Typeset in Galliard

by Apex CoVantage, LLC 


\title{
5 China's Belt and Road Initiative through the lens of Central Asia
}

\author{
Roman Vakulchuk and Indra Overland
}

\section{Introduction: a new Silk Road for Central Asia}

The Belt and Road Initiative (BRI), aimed at connecting China, Europe and countries located along routes between China and Europe, was suggested by Xi Jinping in September 2013. This Chinese initiative envisages the completion of more than 100 small- and large-scale infrastructure projects that would improve China's connectivity with Western Europe via Central Asia and Russia, including roads, railroads, pipelines, industrial parks, and special economic zones. The five Central Asian states - Kazakhstan, Kyrgyzstan, Tajikistan, Turkmenistan, and Uzbekistan - are an important geographical focus of the project.

BRI encompasses nearly half the world's population, vast resources and 40 percent of global GDP (gross domestic product). As of 2017, 68 countries - including the Central Asian states - had expressed an interest in joining BRI. The plan is that the infrastructure will be accompanied by large-scale investment from Chinese companies and institutions such as the Silk Road Foundation with funds of US\$40 billion, and the Asian Infrastructure Investment Bank (AIIB) with funds of US\$100 billion. In addition, Beijing plans to provide development aid to the countries that participate in BRI.

There has been a steady increase in the influence of China in Central Asia since the early 1990s (Indeo 2017, p. 37). The total trade turnover between China and Central Asia grew 60-fold between 1991 and 2016, from US\$500,000 million to 30 billion, excluding significant informal trade by small-scale entrepreneurs. Currently, 23,000 students from Central Asia study in China and more than 700,000 people travelled between Central Asia and China in 2015 (Forbes 2017a). Because of BRI, China is likely to remain the biggest investor in the region in the future, far exceeding the potential economic footprint of Russia and the West (Laruelle 2018, p. xii). China has also become one of the biggest importers of Central Asian energy resources. After BRI was launched, Beijing rapidly scaled up its public diplomacy and strengthened its soft power presence, especially in education and culture, thus increasingly becoming a norm-setter in Central Asia (Dave 2018, p. 99).

But how have Central Asian actors come to view China since BRI was launched? To what extent is the population aware of the risks and opportunities brought by 


\section{Roman Vakulchuk and Indra Overland}

BRI? The fact that China made a promise to Central Asia concerning BRI should in theory improve the perception of China in the region. This should presumably also help project Beijing's image as source of economic opportunity for Central Asia's stagnant economies.

There is a growing body of scholarly literature on BRI and its implications for different parts of the world, including Central Asia (e.g. Amighini 2017; Ehteshami \& Horesh 2018; Lim et al. 2016; Yilmaz \& Changming 2018). However, less attention has been paid to the study and perception of BRI in Central Asia from the point of view of local actors (e.g. Laruelle 2018; Sternberg, Ahearn \& McConnell 2017). This chapter makes an empirical contribution by studying whether the launch of BRI has led to a shift in Central Asian attitudes towards and perceptions of China. We discuss the interaction between China and each of the five Central Asian states, highlighting local attitudes towards and perceptions of the big neighbour. We focus on economic interaction, infrastructure and education initiatives as they are among the main pillars of the BRI agenda, while acknowledging that cooperation on political, diplomatic, and security issues has been no less important for shaping perceptions of China in Central Asia.

One limitation of our analysis should be mentioned. It is difficult to separate BRI analytically from other ongoing projects within the bilateral cooperation between China and the Central Asian countries, "as many bilateral agreements are now being brought under the Silk Road and BRI umbrella" (Dave 2018, p. 100). We attempt to overcome this limitation by tracing changes in attitudes towards and perception of China in general since 2013, when BRI was announced, and whether the change can be attributed to the promotion of BRI.

\section{Central Asia and great powers}

Especially during the decade from 2008 to 2018, China became one of the most important players in Central Asia, a region that remains largely unintegrated. In fact, Central Asia, while a culturally and historically homogenous region, remains one of the least integrated regions in the world. Apart from a zone free of nuclear weapons established in 2006, ${ }^{1}$ which is the only region-wide organization, there are no regional platforms that bring together all five Central Asian states on a regular basis. All other organizations, such as the Commonwealth of Independent States (CIS), the Collective Security Treaty Organization (CSTO), the Eurasian Economic Union (EAEU), the Organization of Islamic Cooperation (OIC) and the Shanghai Cooperation Organization (SCO) include third states, among which are Afghanistan, China, Pakistan and Russia. Third parties often have their own priorities and promote and sometimes impose their own agendas that only strengthen the disintegration processes. Central Asia was once also considered to be a part of the so-called Great Game, ${ }^{2}$ and major powers continue to play a role in the region (Xin 2016, p. 124). Some scholars even argue that the Great Game contest resumed after the terrorist attack of $9 / 11$ and continues to influence the policies of the great powers towards Central Asia (Cooley 2012; Kim \& Indeo 2013). 
China realized how internally disconnected the region is and pursued a bilateral approach in its relations with Central Asian governments from the late 1990s onwards. The Chinese have acted patiently and pragmatically and over time have managed to build working relations with each of the five countries, including Turkmenistan, where the construction of the Turkmenistan-China gas pipeline can be viewed as a major Chinese success story in a country where both Russia and the United States have struggled to maintain a foothold. Despite the fact that BRI is a regional project, it is likely that, in the short and medium term, the collaboration between China and Central Asia will be based primarily on bilateral relations. Following China's example, Russia, the United States and international donors have taken an increasingly bilateral approach rather than a regional one, as the former is more pragmatic and brings more practical benefits in dealings with Central Asian countries.

Central Asia is a complex region characterized by both dynamism and stagnation and requires new approaches and tools for better comprehension by external actors. China needs an adequate understanding of these changing dynamics while also being an important source that feeds this dynamism through the BRI agenda. The region has many internal problems and conflicts, which explains persisting non-integration. Among the factors that contribute to these problems are regional competition for leadership, corruption, weak governance and economic stagnation, tensions over water resources, ageing infrastructure, and high costs of cross-border trade. For instance, Central Asia performs weakly on the Ease of Trading across Borders Index, where out of 189 countries Kyrgyzstan is ranked number 84, Kazakhstan 123, Tajikistan 149 and Uzbekistan 168 (World Bank 2018). In fact, informal barriers to trade limit cross-border cooperation and raise trade costs in Central Asia (Vakulchuk \& Irnazarov 2014; Vakulchuk, Irnazarov \& Libman 2012). If they are not eliminated, these informal barriers pose a risk to China's grand strategy of improving regional connectivity through BRI.

\section{China in Central Asia: soft power and knowledge gaps}

To make BRI a success, it is important for China to understand how it is perceived in Central Asia. Despite the region's lack of integration, perceptions of and attitudes towards China are similar across all five Central Asian countries. There are mixed perceptions of China, ranging from negative to positive. Several scholars agree that there is a significant difference in the perception of China by the ruling elites and by the broader public. Elites tend to be pro-China, while the public is sceptical of Chinese economic and cultural expansion (e.g. Y - W Chen 2015; Kassenova 2017; Laruelle \& Peyrouse 2012; Peyrouse 2016; Toktomushev 2018; Burkhanov 2018). And yet, there is also a perception shared by the local elites that it is risky to rely excessively on China as a source of foreign investment (Lain 2018, p. 3). Although perceptions of China are similar, there is little consensus among the Central Asian states about the degree of Chinese influence in the region (Shahbazov 2016). 


\section{Roman Vakulchuk and Indra Overland}

Peyrouse $(2016$, p. 18) notes that the main message from numerous Chinarelated surveys conducted in Central Asia is that "China remains a challenge for Central Asia". The region's sinophobia is viewed as one of the major stumbling blocks for BRI (Farchy 2016; Kassenova 2017). Four factors can explain sinophobic attitudes towards China among the broader public. First, during the Soviet period China was presented and perceived as a threat, and these ideas linger on. Second, the population of Central Asia remains under-informed about China's activities in general and BRI in particular (Dave 2018). This in turn feeds into the notion that China is a threat. Third, the influx of Chinese immigrants constitutes a major concern for the population (Jochec \& Kyzy 2018; Garibov 2018). Fourth, religion plays a role in Central Asian attitudes towards China, as Central Asia's Muslim population is concerned about Chinese government policy in the Xinjiang Uyghur Autonomous Region.

Another stumbling block for China-Central Asia relations is that both sides have limited knowledge of each other (Peyrouse 2016). This relates both to professional ties and people-to-people relations, the latter being one of the main objectives of BRI. There are only a few think tanks and research centres in Central Asia that specialize in China studies (e.g. the China Studies Centre in the Library of the First President of Kazakhstan in Astana and the China and Central Asia Studies Centre (CCASC) at the KIMEP University in Almaty - both opened in 2017). Also, China has only started building its knowledge about the region after 2014, as part of BRI public diplomacy effort (Dave 2018). New think tanks were established in China after 2013 in order to study countries that are part of BRI (D Chen 2015). China also opened 11 Confucius Institutes across Central Asia to promote language and culture. Most of them, however, were set up prior to the launch of BRI (see Table 5.1). And yet, as Zhao Huasheng, director of the Centre for Russia and Central Asian Studies at Fudan University, notes, "I do not think China has done enough. They have work to do to create a favourable image" (Zhao cited in Farchy 2016). There is scepticism among foreign partners when China's government promotes its ideas, values and visions, as they are perceived "as pure propaganda" (D Chen 2015). Thus, there is a persistent imbalance between China's economic and soft power presence in the region.

Table 5.1 Number of Confucius Institutes in Central Asia by country

\begin{tabular}{lr}
\hline Kazakhstan & 4 \\
Kyrgyzstan & 3 \\
Tajikistan & 2 \\
Uzbekistan & 2 \\
Turkmenistan & 0 \\
Total & 11 \\
\hline
\end{tabular}




\section{Kazakhstan and China: facts and perceptions}

Kazakhstan is rich in natural resources and an important transit partner for Beijing. China has overtaken Russia to become Kazakhstan's main trade partner; however, the relationship has received much less attention than that between China and Russia (e.g. Overland \& Kubayeva 2018; Lo 2008; Braekhus \& Overland 2007). China stands for 16 percent of Kazakhstan's total trade, and external debt to China amounts to US\$12.3 billion. Major Chinese banks such as the Bank of China and the Industrial and Commercial Bank of China operate in Kazakhstan. Chinese companies invest in Kazakhstan's extractive industries. Sinopec invested US\$1.4 billion, and China International Trust and Investment Corporation (CITIC) and China Investment Corporation (CIC) recently invested US\$0.95 billion. China National Petroleum Corporation (CNPC) invested more than US\$12 billion in petroleum production and provided US\$6.2 billion to build oil and gas pipelines in Kazakhstan to facilitate the supply of energy resources from Central Asia to China (International Centre for Trade and Sustainable Development 2016). Chinese firms control nearly a quarter of Kazakhstan's oil production (Wilson 2016). During the years 2006-2009, the Kazakhstan-China oil pipeline was built and launched. In addition, the gas pipeline Beineu-Bozoi-Shymkent helps connect small gas pipelines in Kazakhstan into one system; this in turn expands gas exports to China.

In the long run, BRI may help make Kazakhstan a major logistical hub in Central Eurasia. Kazakhstan's Nurly Zhol development programme has many of the same objectives as BRI but at a domestic Kazakh level, and the Kazakhs have agreed to coordinate it with BRI. Similar to Kyrgyzstan, Kazakhstan seeks to strengthen its mediation role in China's trade relations with the entire region through BRI. The Western Europe-Western China international transport corridor crosses the territory of Kazakhstan and is intended to play an important role in boosting Chinese trade transit through the country. Furthermore, Khorgos, an international dry port and border cooperation centre, was constructed on the Kazakh border in 2015 , providing Kazakhstan with the possibility of connecting to the Chinese port of Lianyungang. Its aim is to boost cross-border trade and cooperation and reach a capacity of 500,000 cargo containers by 2020, thus becoming the world's largest dry port (The Astana Times 2016). The centre, ambitiously referred to as New Dubai, allows for duty-free trade and has an industrial logistics hub. The Khorgos hub can be viewed as a flagship and gamechanging project of BRI, on a level with the China-Pakistan Economic Corridor (CPEC) and the Hambantota port in Sri Lanka (Dave 2018, p. 99).

In 2015-2016, five agreements were signed, aimed at creating cluster cooperation zones in transport infrastructure, trade, processing industries, construction, agriculture and other areas. Moreover, the volume of Chinese investment has increased nearly sevenfold over the last five years (Forbes 2017b). In 2015, China announced the transfer of 51 industrial production sites from China to Kazakhstan, a milestone in the growing Chinese engagement with Kazakhstan. As of 2017, 12 sites, mainly from the processing industry, have been transferred. 
In terms of soft power, China plays a more visible role in Kazakhstan than in any other Central Asian state. Four Confucius Institutes operate in the country in collaboration with local institutions and China also became an attractive destination for outbound Kazakh students from 2008 onwards. It is ranked second after Russia as the most popular destination for Kazakh students, and in 2007, about 3,000 Kazakhs studied in China (Kaukenova 2017). In 2016, the China Scholarship Council, a government agency that assists foreign students in China, reported that the number of Kazakh students had increased nearly fourfold, to 12,000 (Farchy 2016). The share of Kazakhs who study using student loans from the Chinese government was 32.7 percent, whereas those receiving student loans from the government of Kazakhstan was only 2.7 percent (Kaukenova 2017). These statistics show a clear trend towards rising popularity for China since 2007, and yet it lags far behind Russia, which hosted 73,000 Kazakh students in 2016 (Rakhman Alshanov in Today.kz 2017).

In Kazakhstan it is possible to distinguish between two rough groups, which can be referred to as sinophobes and sinophiles (Peyrouse 2016, pp. 17-18). The former is represented by the political and economic elite, whereas the latter is represented mainly by the political opposition, Uyghur associations and small business representatives. These two camps can be found in all five states of Central Asia. The dynamics behind the simple duality of these two categories are much more complex (Exnerova 2018, p. 134).

Kazakhstan's political elite has been supportive of close economic ties with China (Kassenova 2017), and the government has referred to and learnt from China's economic model in the post-communist reform process (Vakulchuk 2014, p. 181). Despite China's increased economic engagement with Kazakhstan and the growing interest in studying in China among the young, the overall attitude towards China in society can be viewed as the least positive in the region. In a survey conducted by the Eurasian Development Bank, only one in six people in Kazakhstan views the big neighbour as a friend, and China is ranked among the top three unfriendliest countries (Farchy 2016).

Compared to Kazakhstan's political leaders, the expert community tends to take a more critical view of China's increasing economic expansion, and yet their analyses and views are mixed and highlight the complexity of issues involved in the bilateral relationship (Laruelle \& Peyrouse 2012). According to Dosym Satpayev (cited in Farchy 2016), a Kazakh political scientist and expert,

[s]tatistically China is a very important trade partner of Kazakhstan. But a lot of people in Kazakhstan don't think of China as a big investor. They think of China as a big problem - people here believe China tries to increase its economic influence without any benefit to our countries.

Not only society but also the expert community remains under-informed about the scope and extent of Chinese-Kazakh relations. Konstantin Syroezhkin (cited in Razumov 2016), a local sinologist, notes that "there is informational reticence ['informacionnaja zakrytost'] in financial and economic cooperation between 
Kazakhstan and China. No contracts are published or terms for obtaining loans are disclosed . . . the official statistics fail to separate between Chinese FDI and credits". Regarding BRI in particular, Dave (2018, p. 100) quotes a local expert who noted that "everyone talks about them [BRI projects], but nobody has seen them". Kassenova $(2017$, p. 113$)$ emphasizes that there is no detailed information about BRI projects in Kazakhstan and this erodes trust in the government and strengthens the perception of China as a threat.

Society also remains sensitive to other sides of Chinese expansion. In 2016, protests took place in several parts of Kazakhstan (including Atyrau, Aktobe, Semey) against new amendments in the land code pertaining to the sale of land to foreigners. Many Kazakhs raised concerns about China's purchase of land. Furthermore, disputes and clashes take place regularly between Kazakh and Chinese workers at joint ventures. The Chinese workforce is usually better paid than the local one and this causes discontent on the part of the Kazakh workforce.

Moreover, in January 2017, there was a public protest in Astana against marriages between Kazakh women and Chinese men where the protesters requested the withdrawal of the Kazakh citizenship of women who marry Chinese men. Also, the activists suggested charging Chinese men a one-time tax of US\$50,000 for marrying a local woman (Lenta 2017). However, Svetlana Kozhirova, a local sinologist, noted that the number of Chinese marrying local women is in fact small and that local mass media tend to distort perceptions about China (Kozhirova 2017). Beate Eschment, a Central Asia expert, notes that there is a paradox: the anti-China sentiment is strong in the country, and yet it is China that can help the country fight the economic crisis by attracting finance and investment (Volkov 2016). And yet, some experts argue that there has also been a gradual positive shift in the perception of China in Kazakhstan in recent years (Razumov 2016).

\section{Kyrgyzstan and China: facts and perceptions}

In the early 1990s, Kyrgyzstan lost many of its economic ties to the other former Soviet republics. To recover from the difficult early years of independence, the country found a new niche and became a transit hub for trade between China, Kazakhstan and Russia. The latter was also facilitated by Kyrgyzstan's accession to the World Trade Organization (WTO) in 1998 and China's accession in 2001. However, Kyrgyzstan has largely lost this status, and its capacity for re-exports has been limited since it joined the Eurasian Economic Union in 2015 and adopted stricter trade rules.

Unlike Kazakhstan, where China's presence is big due to natural resources and convenient logistics, Kyrgyzstan is of less interest to China due to the small size of its market and its geographic location. Nonetheless, the Chinese presence in the country has had significant repercussions due to the economic projects promoted by Beijing. Chinese companies are involved in the construction of major roads in Kyrgyzstan; the construction of the Datka Kemin electricity transmission line worth US $\$ 389$ million provided by the Chinese partner was completed in 2015; 


\section{Roman Vakulchuk and Indra Overland}

and Chinese companies built two petrol stations in Tokmak and Kara-Balta. Chinese firms also participate in natural resource extraction (e.g. gold mining).

The major opportunity for Kyrgyzstan lies in the construction of the ChinaKyrgyzstan-Uzbekistan railway, which commenced before BRI, and the Turkmenistan-China gas pipeline, both of which cross Kyrgyz territory. In particular, the railway project is seen with great hope, as it can potentially provide annual fees of US\$200 million for freight transit. Moreover, if the project is implemented, it should boost transport connectivity in Kyrgyzstan and Central Asia. Kyrgyzstan and Uzbekistan seek to include the railway project under the BRI umbrella (Putz 2017). However, there are several issues that can pose a risk to this project and explain why the project has not moved forward for many years: difficulties in the adoption of technical standards and norms; the gauge width difference $(1,435 \mathrm{~mm}$ vs. $1,520 \mathrm{~mm}){ }^{3}$ sources of funding; and the Chinese requirement to provide a deposit in the form of access to natural resources in Kyrgyzstan.

While for China the bilateral projects in Kyrgyzstan are small, they are significant for Kyrgyzstan. From 2012 onwards, China became Kyrgyzstan's biggest bilateral creditor: out of US\$3.7 billion external debt, US\$1.4 billion was issued by the Export-Import Bank of China (Abdrisaev 2016). Through its participation in BRI, Kyrgyzstan risks getting caught in a "debt trap" (see Figure 5.1). As Fernholz (2018) notes,

[i]n the past, China has responded to the debtors inconsistently and hasn't followed best practices adopted by international lenders working with poor countries. Sometimes, the debt has been forgiven; other times, disputed territory or control of infrastructure has been demanded as recompense.

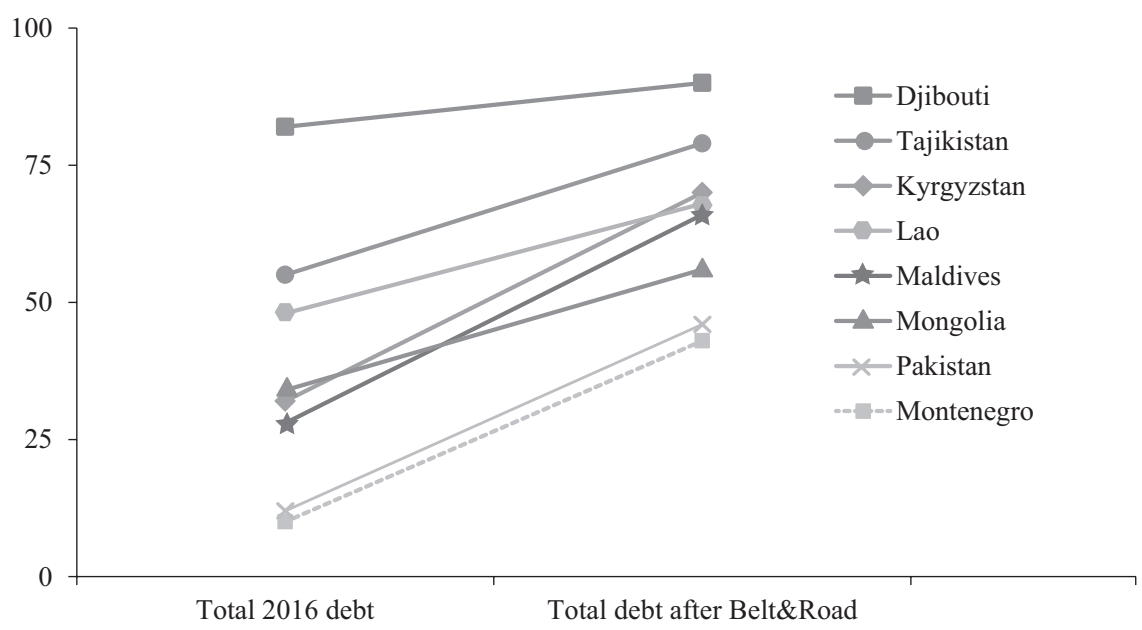

Figure 5.1 Countries at risk from BRI debt (vertical axis showing percentage of GDP) Source: Center for Global Development in Fernholz (2018). 
Debt dependency and the risk of loss of sovereignty are generally of concern for the Kyrgyz population (Jochec \& Kyzy 2018). A further rise in debt due to BRI can only reinforce this concern.

China's soft power projections have had only limited influence in the country. Beijing has been mainly engaged in promoting culture-oriented and educational projects in Kyrgyzstan. In 2013, almost 2,000 students from Kyrgyzstan studied in China, while 1,000 Chinese students studied in Kyrgyzstan (Kabar 2013). Three Confucius Institutes have been opened on the premises of local universities.

Most of Kyrgyz society views China's cultural expansion rather negatively. A potential influx of Chinese immigrants is viewed as the most significant risk of continued Chinese investment in Kyrgyzstan (Jochec \& Kyzy 2018). This has been fuelled also by clashes between local and Chinese workers at the TBEA Company, which builds electricity transmission lines.

And yet, the Chinese policy of soft power catch-up shows some positive dynamics. According to the 2017 survey of the Baltic Surveys/Gallup, about 60 percent of those surveyed assessed relations between Kyrgyzstan and China positively, and 32 percent viewed China as an economic partner. In contrast, the 2016 results showed lower numbers: 54 percent and 21 percent respectively (Siar - Consult 2017). Over time, China's soft power and public diplomacy efforts in Kyrgyzstan are likely to increase and can improve China's image in the country.

\section{Tajikistan and China: facts and perceptions}

China is one of Tajikistan's main economic partners. In 2016, the total trade turnover between the two countries amounted to US\$885 million. The trade balance was largely in favour of China; more than 90 percent was Chinese imports to Tajikistan. In 2015 , US $\$ 238$ million or 81.2 percent of the total FDI that the country managed to attract was from China (Ulmasov 2016). Similarly to Kyrgyzstan, there is a debt trap risk for Tajikistan in case of deeper cooperation within BRI that may negatively affect the way China is perceived (see Figure 5.1).

In Tajikistan, AIIB plans to construct and expand the roads in the country, including the road that connects Tajikistan and neighbouring Uzbekistan. In 2016, AIIB and EBRD provided a direct loan worth US\$55 million (US\$27.5 million each) to modernize some parts of this road (EBRD 2016). This project is aimed at facilitating China's access to the markets of Central Asia, also stimulating the export of Chinese goods to the region. China has a common border with Tajikistan, and over the last several years Beijing has provided Dushanbe with a number of loans to construct roads and tunnels and modernize energy infrastructure. There are also plans for one of the branches of the Turkmenistan-China pipeline to cross Tajikistan. In 2014, CNPC and Tajiktransgas signed an agreement to start construction.

Several issues can complicate relations between the two countries and affect how China is perceived in Tajik society. The two countries have a territorial 


\section{Roman Vakulchuk and Indra Overland}

dispute in the eastern Pamirs. The first agreement on disputed territories was signed in 1999, when Tajikistan retained one piece of land but conceded another to China. In 2011, the dispute about another contentious territory was resolved: out of 28,000 square kilometres that China had initially claimed, it received 1,000 square kilometres (3\% of Tajikistan's territory) in the eastern Pamirs, while Tajikistan got a partial debt write-off (Smirnov 2011; Eurasianet 2016). In 2017, the Tajik scientific community raised concerns about another possible territorial claim of China to Tajikistan: China's "policy is far beyond the goal of reaching historical fairness: the disputed land claimed by China is rich in gold and other precious metals and minerals" (Eureporter 2017).

As for education, two Confucius Institutes operate in the country, and about 5,000 Tajik students study in China, 400 with study loans from the Chinese government (Ulmasov 2016). Learning Chinese has become increasingly popular over the last years, especially in small towns that depend economically on Chinese companies (Tiido 2018). However, as in the other Central Asian republics, there is a degree of distrust of Beijing in Tajik society.

In general, local political elites are loyal to and supportive of China. It is commonly agreed that China can strengthen the region's stability and Beijing has also established military cooperation with Tajikistan (Shahbazov 2016). Beijing is viewed as a neighbour who is increasingly becoming an ally. At the same time, there is some indication that local entrepreneurs are unhappy about the growing Chinese economic presence (Peyrouse 2016).

The sociological surveys of 2008 and 2016 carried out by the Institute of Oriental Studies under the Academy of Sciences of the Republic of Tajikistan show a generally positive attitude of the local population towards China. According to a poll carried out in spring 2016, more than 90 percent of the respondents view Chinese engagement with Tajikistan positively (see Central Asia Monitor 2016). The population of Tajikistan considers China the second most attractive political and cultural partner after Russia. A comparison of attitudes in 2008 and 2016 indicates that China has gradually replaced Iran in the public eye even though Russia is still perceived as the most important partner. In 2008, only 8 percent of the surveyed people regarded China as the country projecting the biggest influence, but in 2016 this number rose to 12.5 percent. Russia's position declined from 89 percent in 2008 to 75.4 percent in 2016. Iran was seen as most influential by 9 percent in 2008 and by only 5.3 percent in 2016 .

However, there is little evidence that BRI has changed the perception of China among the Tajiks much after 2013. Unlike Kazakhstan, where the BRI has spurred an active discussion of the role of China, BRI has gained less attention in Tajik society. Even though China is perceived more positively than before, this change has not been significant and Chinese-Tajik cooperation has not been widely discussed by the media or the expert community since 2013 . The population remains poorly informed about BRI. The form of interaction between the governments of two countries has remained largely unaltered: closed high-level political meetings with little disclosure of information to the broader public. 


\section{Turkmenistan and China: facts and perceptions}

Turkmenistan is known for being a reclusive state and one of the least accessible countries in the world. Despite this, the country has continuously developed its relations with China since 1991. Official status as a non-aligned state helps Turkmenistan remain autonomous in its foreign policy and so the close relations with China have been an exception in Ashgabat's largely isolationist foreign policy.

Energy in general and the supply of natural gas from Turkmenistan to China in particular are at the core of bilateral relations between the two states. At present, China absorbs more than half of Turkmenistan's natural gas exports. By May 2016, Turkmenistan had cumulatively supplied China with 138.6 billion cubic metres of natural gas (Neftegaz 2016). The Turkmenistan-China pipeline has three pipes and a fourth pipe is planned, which would bring the total capacity to $74-80$ billion cubic metres. Turkmenistan is expected to play an important role in China's energy supply and energy security in the next decade, in line with BRI objectives and China's economic development goals. By 2030, China seeks to import 270 billion cubic metres of natural gas, up from 53 billion in 2015 (Solovieva 2016).

We should note the high degree of economic dependence of Turkmenistan on China. For Turkmenistan there is a risk of financial over-dependence on China (Lain 2018, p. 3). Turkmen natural gas exports to China can be viewed as compensation for the millions of credits it has received from Beijing. In 2011, China provided credit worth US\$8 billion and issued another one in 2013. The trade turnover between China and Turkmenistan reached US\$10 billion in 2013 but dropped to US\$5.9 billion in 2016 (Chronicles of Turkmenistan 2017). Currently, more than 40 Chinese companies operate in Turkmenistan.

Turkmenistan is the only country in the region that has no Confucius Institute; however, a Turkmenistan Centre was established at the Oil University in Xi'an, China, in May 2017 (Turkmenistan Today 2017). This is the second study centre, as the first one was established in China in 2014. In 2014, about 1,500 students from Turkmenistan studied at Chinese universities (Izimov 2016). Given the limited information available, it is difficult to identify the perceptions and views of China by the local population.

\section{Uzbekistan and China: facts and perceptions}

Along with Kazakhstan, Uzbekistan is one of the economic locomotives of Central Asia. Even during the years of isolationist policy under former president Islam Karimov, Uzbekistan sought to deepen its trade and economic ties with China. In 2015, the trade volume reached nearly US\$3 billion, higher than Tashkent's overall trade with Russia. In 2016, the trade volume reached US $\$ 4.2$ billion. The two countries agreed to increase their bilateral trade by US\$10 billion by 2020 (Sputnik Uzbekistan 2017a). Energy is an important part of bilateral cooperation, and in 2013 the two countries signed deals worth US\$15 billion for the 
development of oil, gas, and uranium fields in Uzbekistan (South China Morning Post 2013).

Uzbekistan is an attractive economic partner for China, as it has one of the most diversified economies in Central Asia. In total, Chinese firms have invested about US\$8 billion in the Uzbek economy since 1991. China also acted as donor, providing grants amounting to US\$285 million for the implementation of more than 40 projects in the areas of health care, education, agriculture, water resources and labour. More than 700 companies, both Chinese and joint ventures, are engaged in oil and gas exploration, pipeline construction, transport infrastructure, telecommunications, textiles, irrigation, and new sources of energy in Uzbekistan.

According to the Uzbek National News Agency ( Uza 2016), several big investment projects are being developed. One of them is a high-technology park in the Jizzakh special industrial zone formed in 2013. Uzbekistan also plays an important role as part of BRI, in particular in joint transport and logistics projects. The completion of the electrified Angren-Pap Railway in 2016 connected the Ferghana valley with central parts of the country. This railway will also be an important part of regional BRI-related connectivity plans. Using this railway, China should also gain easier access to Central Asia and ultimately South and Western Asia and Europe.

As for culture and education, the Chinese Central University for Nationalities opened an Uzbek Language Department. The Uzbek language is also taught at Beijing University, and an Uzbekistan Center and education-related exchange programme were launched at Shanghai University (Central Asia Monitor 2016). Two Confucius Institutes operate in Uzbekistan. The first opened in Tashkent in 2004 and was the first to be established in Central Asia. ${ }^{4}$ In 2014-2015, the Chinese government provided a grant to 120 Uzbek students and interns as part of a bilateral agreement under the auspices of the Shanghai Cooperation Organization (SCO). In addition, 50 Uzbek students studied at the Lanzhou University as part of the Confucius Institute programme (Sputnik Uzbekistan 2017b).

There is still a gap between economy and culture when it comes to China's presence in Uzbekistan. Uzbek society has a vague understanding of China. The isolationist policy of Karimov's government contributed to this. Also, since 1991, South Korea more than China has been the role model for the Uzbek government. Chen and Günther (2016) found that the perception of China at the individual level has not been affected by BRI. They analyzed statistics from Google Trends and the Yandex search engine and found that there has not been a significant change in Uzbeks' interest in China since 2013. Chen and Günther (2016) concluded that “[1] ocal Uzbekistanis' perception of China varies depending on the issue. Respondents seem to have some impression of China's increasing cultural, economic and political influences. However, they do not necessarily know details of projects, such as the OBOR". There is a lack of think tanks and research centres that specialize in Chinese issues and systematically inform the public about the country.

\section{Has BRI changed China's image in Central Asia?}

Since BRI was announced as China's grand strategy in 2013 and the first BRI projects were launched, there has not been a major change in the perception of 
China in Central Asia. Beijing's ties with the region have political and economic roots dating back to the early 1990s, and BRI has not yet become a game changer for local attitudes towards the big neighbour. The current perceptions of China, although mixed, were largely formed within the framework of bilateral relations that started in 1991. However, the announcement of BRI has expanded the discussion of China and its role in the region among Central Asians.

Analysing the region's perceptions of China and BRI, we can see similar patterns across all five Central Asia countries. There are some differences, but they are not significant. Each country is attracted by Chinese economic projects and educational opportunities; but there is also a persistent anti-Chinese sentiment across Central Asia related to potential Chinese demographic and cultural expansion and increased financial debt dependence that may follow economic expansion.

In the long run, BRI can boost infrastructure development among Central Asian countries and facilitate trade among them and with third countries. This can pave the way for a more positive attitude towards China. However, without more transparency, the more China is involved economically in the region through BRI, the more likely it will face resistance from the broader public (Sternberg, Ahearn, McConnell 2017; Dave 2018). Chen and Günther (2016) note that local perceptions of China in Uzbekistan are unlikely to change if the population remains poorly connected to the high-level political interaction on BRI. This also applies to other countries of Central Asia.

The local authorities have been passive and unsystematic in informing the public about ongoing projects with China. The expert community in Central Asia has also been critical of the general lack of information and transparency of Chinese investment and business activities in the region. Therefore, while the broader public expects more economic opportunities from BRI, it remains under-informed and concerned about the consequences of further Chinese economic expansion.

Chinese actors need to carry out more proactive information campaigns that reach not only to the local elites but also to the broader public. This is easier said than done. First, Chinese businesses have been criticized for their lack of transparent approach as well as corrupt practices when doing business in other parts of the world (e.g. in Africa; see Geerts, Xinwa, Rossouw 2014). Second, there is also a challenge of limited policy coordination between the Chinese central government and regional authorities (Stokke, Vakulchuk \& Overland 2018). Regional Chinese authorities in the border regions often pursue their own agenda, which may differ from that of the central government. Therefore, the official Beijing position may be at odds with the day-to-day practices of local Chinese authorities as well as Chinese entrepreneurs. Regular practices are what shape perceptions; the official position is viewed more as propaganda if practices do not support it.

The Confucius Institutes have so far been ineffective as soft power instruments and do not appear to have improved China's image in Central Asia (Nursha 2018, p. 142). The increasing number of Central Asian students in China is unlikely to have an immediate effect and drastically change local perceptions of China. 


\section{Roman Vakulchuk and Indra Overland}

However, in the long term the Confucius Institutes and especially the Central Asians studying in China may become game changers. As growing numbers of Central Asians learn to speak and read Chinese and/or have positive personal experiences of living in Chinese society, perceptions may shift on a larger scale.

The region's continuing internal challenges and lack of integration can threaten the BRI's sustainability. However, the replacement of Islam Karimov by Shavkat Mirziyoyev as President of Uzbekistan may change this picture. Uzbekistan is the most populous and most centrally located country in the region. The far more positive stance of Mirziyoyev towards trade and cooperation with the neighbouring countries is highly convenient for China's BRI initiative and may lay the ground for its acceleration.

Last but not least, a concern shared by many in Central Asia is that "the economic benefits felt by local populations in Central Asia will not be as substantive as the Chinese BRI vision suggests - namely, if projects and investments are not managed properly" (Lain 2018, p. 2). Some Chinese entrepreneurs have also questioned the success of BRI and complained about widespread corruption, weak governance, and limited local capacity to manage large-scale investment projects. As Laruelle (2018, p. xi) points out, "like all foreign investors, they are evidently not immune to the region's ills". Moreover, a rapid increase in BRIrelated investment in the region may strengthen bad governance and corruption, provoke rent-seeking behaviour and competition among various interest groups (Cooley \& Heathershaw 2017; Toktomushev 2018). Therefore, the success of BRI in Central Asia depends on the region's ability to tackle internal challenges as well as China's ability and preparedness to assist the countries in meeting their development goals and overcoming internal weaknesses.

\section{Notes}

1 The Central Asian Nuclear-Weapon-Free Zone (CANWFZ) treaty is a legally binding commitment by Kazakhstan, Kyrgyzstan, Tajikistan, Turkmenistan, and Uzbekistan not to produce, acquire, test, or possess nuclear weapons.

2 The Great Game is the analytical concept used to portray a contest among big powers such as the United States, Russia, and China for influence in Central Asia. The concept dates to the 19th century, when the Russian and British Empires were competing for the region that is today's Central Asia and Afghanistan.

3 A solution to gauge width difference was found at the dry port of Khorgos in Kazakhstan, where both the Chinese and the Kazakh gauge width standards apply. In Khorgos, goods delivered by Chinese trains are reloaded on to local Kazakh trains before they can be transported further.

4 Moreover, it is the only institute in the world that was opened according to the agreement signed during a visit to a foreign country by the President of People's Republic of China.

\section{Bibliography}

Abdrisaev, E 2016, 'Госдолг Кыргызстана и ситуация зарубежных стран' (Kугgyzstan's external debt and the situation in foreign countries), Kabar, 17 October. Available from: www.kabar.kg/kabar/full/112595. [22 March 2018]. 
Amighini, A 2017. China's Belt and Road: a game changer? The Italian Institute for International Political Studies (ISPI), Milan.

Arduino, A 2017. 'China's energy interests in Central Asia and Russia' in F Wu \& $\mathrm{H}$ Zhang (eds), China's global quest for resources: Energy, food and water, pp. 119138. Routledge, Abingdon.

The Astana Times 2016. 'Economy news in brief', 9 November. Available from: https://astanatimes.com/wp-content/uploads/2016/11/111.pdf. [22 March 2018].

Braekhus, K \& Overland, I 2007. 'A match made in heaven? Strategic convergence between China and Russia', China and Eurasia Forum Quarterly, vol. 5, no. 2, pp. 41-61. Available from: www.researchgate.net/publication/265455681.

Burkhanov, A 2018. 'The impact of Chinese Silk Road strategy on national identity issues in Central Asia. A media review', in M Laruelle (ed), China's Belt and Road initiative and its impact in Central Asia, pp. 153-161. The George Washington University, Washington, DC.

Central Asia Monitor 2016, ‘Эксперты: “Китай вызывает чувство восхищения и страха в Азии”' (Experts: 'China inspires fascination and causes fear in Asia'), 12 August. Available from: https://camonitor.kz/24846-eksperty-kitay-vyzyvaetchuvstvo-voshischeniya-i-straha-v-azii.html. [22 March 2018].

Chen, D 2015. 'The rise of China's new soft power', The Diplomat, 9 June. Available from: https://thediplomat.com/2015/06/the-rise-of-chinas-new-soft-power/. [22 March 2018].

Chen, D \& Günther, O 2016, 'China's influence in Uzbekistan: model neighbor or indifferent partner?' Jamestown Foundation. China Brief, vol. 16, no. 17, pp. 11-14.

Chen, Y-W 2015, 'A research note on Central Asian perspectives on the rise of China: the example of Kazakhstan', Issues \&્ Studies, vol. 51, no. 3, pp. 63-87.

Chronicles of Turkmenistan 2017. 'Товарооборот Туркменистана с Китаем в денежном эквиваленте значительно сократился’ (Trade turnover in value between Turkmenistan and China has decreased), 6 January. Available from: www.chronotm.org/2017/01/tovarooborot-turkmenistana-s-kitaem-v-denezhnom-ekviva lente/. [22 March 2018].

Cooley, A 2012, Great games, local rules. Oxford University Press, Oxford.

Cooley, A \& Heathershaw, J 2017, Dictators without borders: power and money in Central Asia. Yale University Press, New Haven, CT.

Dave, B 2018, 'Silk Road economic belt: effects of China's soft power diplomacy in Kazakhstan', in M Laruelle (ed), China's Belt and Road initiative and its impact in Central Asia, pp. 97-108. The George Washington University, Washington, DC.

EBRD 2016, 'Road project in Tajikistan becomes first joint EBRD-AIIB investment', European Bank for Reconstruction and Development (EBRD), 24 June. Available from: www.ebrd.com/news/2016/road-project-in-tajikistan-becomes-first-jointebrdaiib-investment.html. [22 March 2018].

Ehteshami, A \& Horesh, N 2018. China's presence in the Middle East. The implications of the One Belt, One Road initiative. Routledge, Abingdon.

Eurasianet 2016, 'Tajikistan, Turkmenistan submit to Chinese capture', 24 June. Available from: https://eurasianet.org/node/79401. [22 March 2018].

Eureporter 2017, 'China territorial claims cause unease in Tajikistan', 23 April. Available from: www.eureporter.co/frontpage/2017/04/23/china-territorial-claimscause-unease-in-tajikistan/. [22 March 2018].

Exnerova, V 2018. 'Transnational ties and local society's role in improving the PRC's image in Central Asia', in M Laruelle (ed), China's Belt and Road initiative and its 
impact in Central Asia, pp. 126-134. The George Washington University, Washington, DC.

Farchy, J 2016, 'Kazakh language schools shift from English to Chinese', Financial Times, 9 May. Available from: www.ft.com/content/6ce4a6ac-0c85-11e6-9456444ab521la2f. [22 March 2018].

Fernholz, T 2018, 'Eight countries in danger of falling into China's "debt trap" , Quartz, 7 March. Available from: https://qz.com/1223768/china-debt-trapthese-eight-countries-are-in-danger-of-debt-overloads-from-chinas-belt-and-roadplans/. [22 March 2018].

Forbes 2017a, ‘За 25 лет товарооборот Китая со странами ЦА вырос в 60 раз’ (Over 25 years' trade turnover between China and Central Asian countries has grown up to 60 times), 11 January. Available from: https://forbes.kz/news/2017/01/11/ newsid_132050. [22 March 2018].

Forbes 2017b. 'Объем китайских инвестиций в Казахстан вырос в 7 раз' (The volume of Chinese investment has risen seven times), 26 January. Available from: https:// forbes.kz/news/2017/01/26/newsid_133690. [22 March 2018].

Garibov, A 2018. 'Contemporary Chinese labor migration and its public perception in Kazakhstan and Kyrgyzstan', in M Laruelle (ed), China's Belt and Road initiative and its impact in Central Asia, pp. 143-152. The George Washington University, Washington, DC.

Geerts, S, Xinwa, N \& Rossouw, D 2014. African's perception of Chinese business in Africa: a survey. Ethics Institute of South Africa, Pretoria.

Indeo, F 2017. 'A comprehensive strategy to strengthening China's relations with Central Asia', in A Amighini (ed), China's Belt and Road: a game changer? pp. 35-51. The Italian Institute for International Political Studies (ISPI), Milan.

International Centre for Trade and Sustainable Development 2016, 'Китай наращивает инвестиции в Казахстан' (China augments investment in Kazakhstan), 28 January. Available from: www.ictsd.org/bridges-news/мосты/news/китайнаращивает-инвестиции-в-казахстан. [22 March 2018].

Izimov, R 2016, 'Руслан Изимов: Китай и Туркменистан: региональное измерение' (Ruslan Izimov: China and Turkmenistan: regional dimension), Central Asian Bureau for Analytical Reporting,17 August. Available from: http://cabar.asia/ru/ ruslan-izimov-kitaj-i-turkmenistan-regionalnoe-izmerenie/. [22 March 2018].

Jochec, M \& Kyzy, JJ 2018, 'China's BRI investments, risks, and opportunities in Kazakhstan and Kyrgyzstan', in M Laruelle (ed), China's Belt and Road initiative and its impact in Central Asia, pp. 67-76. The George Washington University, Washington, DC.

Kabar 2013, 'Интервью Посла КНР в Кыргызстане' (The interview of the ambassador of PRC in Kyrgyzstan), 6 September. Available from: http://old.kabar.kg/ rus/kabar/full/62269. [22 March 2018].

Kassenova, N 2017, 'China's Silk Road and Kazakhstan's bright path: linking dreams of prosperity. Asia Policy, vol. 24, pp. 110-116.

Kaukenova, Т 2017, 'Учеба в Китае: чего хотят и что получают наши студенты' (Studying in China: what do our students want and what do they get), Zakon, 2 March. Available from: www.zakon.kz/4846930-ucheba-v-kitae-chego-khotjati-chto.html. [22 March 2018].

Kim, Y \& Indeo, F 2013, 'The new great game in Central Asia post 2014: the US "New Silk Road" strategy and Sino-Russian rivalry', Communist and Post-Communist Studies, vol. 46, no. 2, pp. 275-286. 
Kozhirova, S 2017, 'Светлана Кожирова: Миф о том, что китайские женихи мечтают увезти из Казахстана казашек - это глупость' (Svetlana Kozhirova: the myth that Chinese men dream to take Kazakh ladies away from Kazakhstan - is foolishness), IA-Centre, 15 May. Available from: http://new.ia-centr.ru/experts/valeriy-sur ganov/svetlana-kozhirova-mif-o-tom-chto-kitayskie-zhenikhi-mechtayut-uveztiiz-kazakhstana-kazashek-eto-gl/. [22 March 2018].

Lain, S 2018. 'The potential and pitfalls of connectivity along the Silk Road Economic Belt', in M Laruelle (ed), China's Belt and Road initiative and its impact in Central Asia, pp. 1-10. The George Washington University, Washington, DC.

Laruelle, M 2018. 'Introduction. China's Belt and Road initiative. Quo Vadis?', in M Laruelle (ed), China's Belt and Road initiative and its impact in Central Asia, pp. x-xii. The George Washington University, Washington, DC.

Laruelle, M \& Peyrouse, S 2012. The Chinese question in Central Asia: domestic order, social change, and the Chinese factor. Columbia University Press, New York.

Lenta 2017, 'В Астане прошел митинг против браков казахских девушек с китайцами' (The protest against the marriages between Kazakh women and Chinese men took place in Astana), 11 January. Available from: https://lenta.ru/ news/2017/01/11/astana/. [22 March 2018].

Lim, TW, Chan, H, Tseng, K \& Lim, WX 2016. China's One Belt One Road initiative. Imperial College Press, London.

Lo, B 2008, Axis of convenience: Moscow, Beijing, and the new geopolitics. Brookings Institution, Washington, DC.

Neftegaz 2016, 'Китай получил 138,6 млрд м3 газа из Туркменистана по сети газопроводов Центральная Азия - Китай’ (China received 138.6 billion cubic metres of gas from Turkmenistan through the Central Asia-China network of gas pipelines), 26 May. Available from: https://neftegaz.ru/news/view/149466Kitay-poluchil-1386-mlrd-m3-gaza-iz-Turkmenistana-po-seti-gazoprovodovTsentralnaya-Aziya-Kitay. [22 March 2018].

Nursha, G 2018. 'Chinese soft power in Kazakhstan and Kyrgyzstan: a Confucius Institutes case study', in M Laruelle (ed), China's Belt and Road initiative and its impact in Central Asia, pp. 135-142. The George Washington University, Washington, DC.

Overland, I \& Kubayeva, G 2018, 'Did China bankroll Russia's annexation of Crimea? The role of Sino-Russian energy relations', in Helge Blakkisrud \& Elana Wilson Rowe (eds), Russia's turn to the East: Domestic policymaking and regional cooperation. Palgrave, Cham, pp. 95-118. Available from: www.researchgate.net/ publication/322158372.

Owen, C 2016, 'Chinese expansion in Central Asia: problems and perspectives', The Foreign Policy Centre (FPC). Available from: https://fpc.org.uk/chinese-expan sion-in-central-asia-problems-and-perspectives/. [22 March 2018].

Peyrouse, S 2016, 'Discussing China: sinophilia and sinophobia in Central Asia', Journal of Eurasian Studies, vol. 7, pp. 14-23.

Putz, C 2017, 'What's next for the Belt and Road in Central Asia?' The Diplomat, 17 May. Available from: https://thediplomat.com/2017/05/whats-next-for-thebelt-and-road-in-central-asia/. [22 March 2018].

Razumov, Y 2016, 'Казахстан и Китай - сближение или имитация?’ (Kazakhstan and China - rapprochement or imitation?), Global Affairs, 31 May. Available from: www.globala airs.ru/global-processes/Kazakhstan-i-Kitai - sblizhenie-iliimitatciya-18190. [22 March 2018]. 


\section{Roman Vakulchuk and Indra Overland}

Shahbazov, F 2016. 'China's economic and military expansion in Tajikistan', The Diplomat, 23 November. Available from: https://thediplomat.com/2016/11/ chinas-economic-and-military-expansion-in-tajikistan/. [22 March 2018].

Siar-Consult 2017, 'Public opinion survey. Residents of Kyrgyzstan, February 15 March 2, 2017'. Baltic Surveys, The Gallup Organization, SIAR Research and Consulting, 2 May. Available from: http://siar-consult.com/wp-content/ uploads/2017/04/Kyrgyzstan-Poll-Winter-2017-Public.pdf. [22 March 2018].

Smirnov, S 2011, 'Китай отщепил часть Таджикистана' (China nibbled part of Tajikistan), Gazeta, 13 January. Available from: www.gazeta.ru/politics/2011/01/12_ kz_3489206.shtml. [22 March 2018].

Solovieva, O 2016, 'В Китае российский газ не ждут' (China does not expect Russian gas), Nezavisimaya Gazeta, 12 August. Available from: www.ng.ru/economics/ 2016-08-12/1_gas.html. [22 March 2018].

South China Morning Post 2013, 'Xi Jinping signs deals worth USD 15b in Uzbekistan', 9 September. Available from: www.scmp.com/news/china/article/1307127/ china-uzbekistan-sign-agreements-worth-us15-billion. [22 March 2018].

Sputnik Uzbekistan 2017a, 'Узбекистан и Китай намерены довести товарооборот до \$10 млрд' (Uzbekistan and China seek to expand trade turnover to USD 10 billion), 24 March. Available from: http://ru.sputniknews-uz.com/economy/20170324/ 5043655/Uzbekistan-i-Kitai-dovedut-tovarooborot-do-10-mlrd.html. [22 March 2018].

Sputnik Uzbekistan 2017b, 'У Узбекистана и Китая схожие позиции по многим вопросам' (Uzbekistan and China have similar takes on many issues), 21 June. Available from: http://ru.sputniknews-uz.com/politics/20160621/3082694. html. [22 March 2018].

Sternberg, T, Ahearn, A \& McConnell, F 2017, 'Central Asian "characteristics” on China's New Silk Road: the role of landscape and the politics of infrastructure', Land, vol. 6, no. 55, pp. 1-16.

Stokke, K, Vakulchuk, R \& Overland, I 2018. Myanmar: A political economy analysis. Norwegian Institute of International Affairs (NUPI) Report. Available from: www. researchgate.net/publication/323018961 [22 March 2018].

Tiido, A 2018, 'Language as a soft power tool in Central Asia', Intersection, 23 February. Available from: http://intersectionproject.eu/article/russia-world/languagesoft-power-tool-central-asia. [22 March 2018].

Today.kz 2017, 'Каждый пятый казахстанский студент учится за границей' (Every fifth Kazakh student studies abroad), 23 August. Available from: http://today. kz/news/kazahstan/2017-08-23/748787-kazhdyij-pyatyij-kazahstanskijstudent-uchitsya-za-granitsej/. [22 March 2018].

Toktomushev, K 2018. 'One Belt, One Road: a new source of rent for ruling elites in Central Asia?', in M Laruelle (ed), China's Belt and Road initiative and its impact in Central Asia, pp. 77-85. The George Washington University, Washington, DC.

Turkmenistan Today 2017, 'Turkmenistan's center was opened in Xi'an city of the people's Republic of China', 26 May. Available from: http://tdh.gov.tm/news/ en/articles.aspx\&article7217\&cat30 [22 March 2018].

Ulmasov, D 2016, 'Интервью посла Китая в Таджикистане Юе Бинь' (The interview of Yue Bin, the Ambassador of China to Tajikistan), Ariana, 7 September. Available from: www.ariana.su/?S=5.1609071136. [22 March 2018]. 
Uza 2016, 'Uzbekistan - China: new stage of cooperation - comprehensive strategic partnership', 23 June. Available from: www.uza.uz/en/politics/uzbekistan-chinanew-stage-of-cooperation-comprehensive-stra-23-06-2016. [22 March 2018].

Vakulchuk, R 2014, Kazakbstan's emerging economy: between state and market. Peter Lang, Frankfurt/Main. Available from: www.researchgate.net/publication/ 299731455.

Vakulchuk, R \& Irnazarov, F 2014, 'Analysis of informal obstacles to cross-border economic activity in Kazakhstan and Uzbekistan', ADB Working Paper, Series on Regional Economic Integration, No. 130. Asian Development Bank, Manila. Available from: www.researchgate.net/publication/323143800.

Vakulchuk, R, Irnazarov, F \& Libman, A 2012, 'Liberalization of trade in services in Kazakhstan and Uzbekistan: analysis of formal and informal barriers'. Economic Education and Research Consortium (EERC), Working Paper No 12/06E. Available from: www.researchgate.net/publication/265008696.

Volkov, V 2016, 'Волна протестов в Казахстане: земельный вопрос как повод?' (The wave of protests in Kazakhstan: the land issue as a pretext?), Deutsche Welle, 6 May. Available from: www.dw.com/ru/волна-протестов-в-казахстане-земельныйвопрос-как-повод/а-19239492. [22 March 2018].

Wilson, WT 2016, 'China's huge "One Belt, One Road” initiative is sweeping Central Asia', The National Interest, 27 July. Available from: http://nationalinterest. org/feature/chinas-huge-one-belt-one-road-initiative-sweeping-central-17150. [22 March 2018].

World Bank 2018, Trading across borders. Available from: www.doingbusiness.org/ data/exploretopics/trading-across-borders. [22 March 2018].

Xin, WL 2016. 'China's One Belt One Road initiative: a literature review', in TW Lim, H Chan, K Tseng \& WL Xim (eds), China's One Belt One Road initiative, pp. 113-132. Imperial College Press, London.

Yilmaz, S \& Changming, L 2018, 'China's "Belt and Road" strategy in Eurasia and Euro-Atlanticism', Europe-Asia Studies, vol. 70, no. 2, pp. 252-276. 